\title{
PENGARUH MOTIVASI, KOMPETENSI DAN DISIPLIN KERJA TERHADAP KINERJA GURU SMA NEGERI SE-KECAMATAN SAMALANGA KABUPATEN BIREUEN
}

\author{
Syahril ${ }^{1)}$ dan Win Konadi ${ }^{2 *}$ \\ ${ }^{1}$ Kepala Sekolah SMA Swasta di Kabupaten Bireuen \\ 2, Dosen FE Universitas Almuslim Bireuen \\ *) email: winmanan1964@gmail.com
}

DOI:

https://doi.org/10.55178/idm.v2i4.217

ABSTRACT

Article history

Received:

September 7, 2021

Revised:

September 13, 2021

Accepted:

September 17, 2021

Page:

$1-8$

Kata kunci:

Motivasi Kerja,

Kompetensi Guru,

Disiplin Kerja,

Kinerja Guru
Penelitian ini untuk mengetahui dan mengkaji pengaruh motivasi kerja terhadap kinerja guru, kompetensi terhadap kinerja guru, disiplin kerja terhadap kinerja guru, dan secara simultan pengaruh motivasi kerja, kompetensi, dan disiplin kerja terhadap kinerja guru SMA Negeri se-Kecamatan Samalanga Kabupaten Bireuen. Objek penelitian adalah 129 guru yang bekerja sebagai guru di SMA Negeri seKecamatan Samalanga Kabupaten Bireuen. Jenis penelitian adalah kuantitatif dengan metode analisis deskriptif dan analisis jalur. Hasil menujukkan, secara analisis deskriptif; a). Motivasi guru termasuk baik dalam mendukung kinerja guru. Skor penilaian Motivasi guru mencapai 85,74\%, b). Tingkat Kompetensi guru, sudah mendekati sempurna, mencapai 90,36\%, c). Disiplin kerja sudah menunjukkan hal yang baik, mencapai 88,74\% dari yang diharapkan untuk meningkatkan kinerja guru. Sedangkan hasil Analisis jalur, menunjukkan adanya pengaruh Motivasi guru terhadap Kinerja guru adalah sebesar 38,54 \%, pengaruh faktor Kompetensi guru terhadap Kinerja guru sebesar 22,89 \%. Juga faktor Disiplin kerja menunjukkan adanya pengaruhnya terhadap kinerja guru, yakni sebesar 7,52\%. Hasil analisis dari nilai koefisien determinasi menjelaskan bahwa kontribusi faktor Motivasi guru, Kompetensi guru dan Disiplin kerja terhadap Kinerja guru SMA Negeri di wilayah Samalanga Kabupaten Bireuen, sebesar 69 \%. Sementara sisanya dari peran yang tidak diteliti yakni sebesar $31 \%$.

\section{Pendahuluan (Introduction)}

Permasalahan mutu pendidikan di daerah Aceh umumnya dan di kabupaten Bireuen, walaupun sudah dicanangkan program "Aceh Carong", masih terus ada kendala dari sisi kompetisi dan kualitas. Terbuti, Aceh masih tergolong rendah secara nasional, terlebih pada klaster SMA, baik hasil diperoleh siswa dan guru.

Oleh karenanya, perlu strategi efektif dan khusus dalam penenaganan ketertinggalan ini dengan peningkatan sumber daya manusia pendidik yang utamanya dan iklim yangmendukung untuk hal tersebut.

Masih terdapat banyak masalah peningkatan mutu ataupun kualitas pendidikan, khususnya di daerah provinsi ujung Sumatera ini. Buktinya mutu pendidikan di Aceh masih jauh tertinggal diukur dari perangkinan secara nasional. Dalam acara "Dialog Tanah Rencong untuk Pendidikan Aceh," diselenggarakan Forum Masyarakat Aceh se-Pulau Jawa (Formaja) secara virtual, pada 16 Mei 2020 disebut bahwa rangking kualitas pendidikan di Aceh masih cukup jauh tertinggal, berada di urutan 25 (infoAceh.net, 2020). Bahkan disebutkan oleh Rektor USK Banda Aceh, Samsul Rizal, mutu pendidikan di Aceh tercatat sebagai salah satu provinsi dengan skor Tes Potensi Skolastik (TPS) terendah secara nasional. Posisi Aceh sejajar dengan beberapa provinsi di bagian timur Indonesia misalnya Maluku, Maluku Utara, NTT, Papua, dan sebagian provinsi lain di Sulawesi (mediaindonesia.com; 2020). 
Apa yang menjadi sebab, semua mempertanyakan, Karena dari sisi anggaran sudah cukup mumpuni, dtamabh dengan masih adanya dana otonomi khusus untuk mendongkrak itu. Dari kaajian teoritis maupun empiris, sebenarnya sudah banyak diketahui, hal yang terkait dengan kendala peningkatan kualitas sumber daya manusia (SDM) tersebut. Kata kunci terus didengungkan, bahwa ada factor internal yang harus hadir dalam setiap pendidik dan peserta didik, yakni motivasi berprestasi misalnya ataupun upya terus memacu kompetensi guru yang utama.

Juga, diharapkan semua komponen dalam sistem pembelajaran yang berorienntasi mutu tersebut sangat penting dan menentukan keberhasilan pencapaian tujuan pendidikan. Namun, semua komponen tersebut tidak akan berguna bagi peserta didik dalam mencari pengalaman belajar yang maksimal, bilamana tidak didukung oleh keberadaan guru yang memiliki motivasi tinggi, disiplin dalam menjalankan amanah secara profesional, sesuai diharapkan dalam Permendiknas Nomor 16 Tahun 2007, tentang standar kompetensi guru, baik dari aspek pedagogik, kepribadian, sosial, dan profesional. Apabila guru menguasai keempat kompetensi tersebut, maka dapat dikatakan guru profesional yang berstandar nasional.

Motivasi kerja mempunyai peranan yang penting dalam hal penumbuhan gairah, merasa senang dan semangat untuk bekerja secara optimal. Guru yang memiliki motivasi kerja yang kuat akan mempunyai banyak energi untuk melakukan kegiatan. Seorang guru yang memiliki intelegensia cukup tinggi bisa gagal karena melemahnyanya motivasi untuk berprestasi dan untuk maju sehingga mengjasilkan kerja yang optimal.

Masih tampak nyata kelemahan dari motivasi kerja guru untuk berprestasi, bukan menjadi rahasia lagi. Fenomena dari acuh tak acuhnya, kepedulian ataupun tanggung jawab sebagian pendidik akan profesi dan tujuan pendidikan menjadi bagian yang tak terpisahkan melemahnya motivasi kerja dikalangan guru. Hal ini harus menjadi perhatian besar bagi pengambil kebijakan.

Namun juga perlu diakui, masih terasanya adanya kegagalan guru dalam melaksanakan tugas tidak sepenuhnya menjadikan guru sebagai kambing hitam, tetapi bagaimana pimpinan yang berkaitan dengan ini mampu mengkoordiansikan potensi yang ada dan kemampuan untuk mendorong motivasi guru terus stabil dan meningkat, hal yang harus ada. Oleh karena itu pada dasarnya motivasi kerja merupakan faktor yang sangat menentukan keberhasilan guru dalam melaksanakan tugas yang dibebankan sekolah kepadanya.

Mutu Sekolah sebagai lembaga pendidikan tidak bisa lepas dari guru. Kualitas dan inovasi guru dengan dukungan kemampuan ICT, sangat membantu perkembangan pendidikan sekolah, dan akhirnya bermuara pada mutu sekolah dan lulusan.

Disamping motivasi guru, tak kalah menjadi perhatian pemerintah tentang kualitas guru yang diukur dari kompetensinya, yakni dari aspek pedagogik atau kemampuan mengelola pembelajaran, pemahaman terhadap peserta didik, perencanaan dan pelaksanaan pembelajaran, evaluasi hasil belajar, dan pengembangan peserta didik untuk mengaktulisasikan berbagai potensi yang dimilkinya. Juga dari kompetensi aspek kepribadian, sosial, dan profesional guru.

Agar kinerja guru lebih baik dan unggul ke depan harinya, banyak hal yang harus diperhatikan. Seperti meningkatkan kelemahan dalam kompetensi guru, juga kedisiplinan. Guru layaknya orang yang menjadi tauladan, harus mematuhi aturan sekolah, dan aturan bidang pendidikan secara umum. Sehingga akan mencerminkan perilaku pendidik yang layak dicontoh oleh peserta didik dan bermartabat di masyarakat.

Betapa pentingnya kinerja guru yang dilandasi oleh motivasi kerja, kompetensi dan disiplin kerja sehingga mendukung kinerja guru dalam mencapai mutu sekolah yang diharapkan. Yang pada gilirannya akan menghasilkan anak didik berprestasi dan meningkatkan akreditasi sekolah. Guru yang profesional sangat dibutuhkan oleh peserta didik. Hal ini menjadi sebuah pertanyaan bagi semua sekolah khususnya guru yang mengajar disekolah.

Penelitian ini dilakukan di SMA Negeri dalam Kecamatan Samalanga Kabupaten Bireuen, untuk melihat kinerja guru dalam bekerja selaku tenaga pendidik yang dilatar belakangi oleh tingkat motivasi kerja, kompetensi dan disiplin kerja. Hal ini menjadi suatu amatan peneliti, disebabkan ketiga hal yang menyebabkan rendagnya kinerja guru dampak dari factor motivasi kerja guru yang belum optima, standar kompetensi yang dimiliki guru masih beragam, dan kedisipilinan yang ditunjukkan oleh telaudan siswa ini masih perlu dipertanyakan.

Wilayah penelitian ini memiliki 3 (tiga) SMA, yaitu SMA Negeri 1 Samalanga, SMA Negeri 2 Samalanga dan SMA Negeri 3 Samalanga. Jumlah semua guru di wilayah ini tercatat sebanyak 129 orang, dengan jumlah siswa rata-rata setiap tahun lebih dari 875 siswa. Output penelitian, untuk memberikan jawaban 
bahwa faktor dugaan, yakni motivasi kerja, kompetensi guru, dan kedisiplinan Guru berpengaruh terhadap kinerja.

\section{Tinjauan Literatur (Literature Review)}

\section{Motivasi Kerja Guru}

Faktor motivasi adalah sangat penting dari sekian elemen yang ada dalam diri pekerja, termasuk guru dalam menhasilkan kerja yang diharapkan. Seseorang akan bersemangat melakukan segala aktivitas sehingga menghasilkan kerja yang diharapkan, dan mencapai tujuan institusi dimana ia bekerja. Karena selalu memperhatikan prilaku (kepribadiannya), semangat untuk bekerja secara efektif dan efisien (Hamalik (2004: 179, Wahyudi, 2012: 101).

Tidak bisa dipungkiri, ada faktor dalam diri dan faktor dari luar diri guru yang mempengaruhi dalam beraktifitas, berinisiatif dan inovasi mengembangkan pendidikan. Motivasi untuk bekerja dan berprestasi salah satu kunci keberhasilan mencapai tujuan, pada semua lini dan organisasi. Karena motivasi kerja guru berfungsi untuk mengarahkan, mengaktifkan dan meningkatkan kegiatan guru sehari-hari sebagai pendidik di sekolah (Sukmadinata, 2009:62; Uno, 2013 :72).

\section{Kompetensi Guru}

Menurut pakar pendidikan, banyak hal yang mempengaruhi kompetensi guru, diantaranya keyakinan dan nilai-nilai, keterampilan individu, pengalaman, ciri dari kepribadiaan guru, adanya motivasi, kompetensi, kemampuan intelektual, dan budaya di sekolah. Hal ini sudah ditetapkan dalam Undang-Undang Republik Indonesia Nomor 14 Tahun 2005.

Pemerintah telah menerbitkan juga Permen Nomor 19 tahun 2005 tentang standar pendidikan nasional bahwa tenaga kependidikan harus memiliki kompetensi pedagogik, professional dan sosial. Maka keempat hal ini harus dimiliki dan diupayakan secara maksimal oleh guru pendidik agar memiliki kompetensi yang standar sesuai ditetapkan. Dengan demikian kompetensi dapat memberikan suatu gambaran tentang skill, knowledge seseorang atau kelompok (team work) serta potensi diri yang dimiliki seseorang terhadap ability dalam melaksanakan pekerjaan yang bervariasi dengan keberhasilan atau kesuksesannya ketika bekerja (Suyuti, 2013:17).

Undang-undang mengharapkan guru memiliki 4 (empat) kompetensi dasar yakni pedagogik, sosial, kepribadian dan profesional. Sehingga, dari pada itu, pemerintah memberikan insentif atas pengakuan ini dengan dana sertifikasi guru.

\section{Disiplin Guru}

Disiplin adalah suatu keadaan tertib dimana orang-orang yang tergabung dalam suatu organisasi tunduk pada peraturan-peraturan yang telah ada dengan rasa senang (The Liang Gie, dalam Wukir, 2013:92). Disiplin memiliki pengaruh yang kuat pada suatu institusi sekolah, apalagi dikaitkan dengan tujuan yang direncanakan sekolah. Apakah dalam hal mutu sekolah, kualitas guru, lulusan dan akreditasi sekolah, karena semua individu mematuhi aturan dan norma-norma sosial yang berlaku (Rivai, 2004 :444).

Penampakan faktor disiplin kerja dapat dilihat dari beberapa indikator. Seperti dinyatakan Mangkunegara dan Octorent (2015), yang intinya kedisiplinan dapat timbul dari adanya, kedisiplinan waktu kerja, kepatuhan terhadap peraturan termasuk penggunaan seragam kerja, serta tanggung jawab guru.

\section{Kinerja Guru}

Kinerja atau performance sering disebut prestasi, yang ditunjukkan dalam penampilan, perbuatan, dan prestasi kerjanya sebagai akumulasi dari pengetahuan, keterampilan, nilai, dan sikap yang telah dimilikinya dalam melaksanakan tugas pembelajaran di sekolah dan bertanggung jawab atas peserta didiknya (Mulyasa, 2013: 88, Supardi, 2013: 54).

Dari aspek-aspek diatas, para pakar menetapkan beberapa dimensi dan indikator dalam mengukur kinerja guru. Diantaranya kemampuan menyusun rencana pembelajaran, melaksanakan dan menilai hasil belajar, melaksanakan pengayaan, dan lainnya (Supardi, 2013: 73).

Oleh karenanya, pedoman yang telah dibuat sebagai standar, akan menuntut guru untuk dapat berkinerja secara maksimal sesuai dengan penugasannya. 


\section{Metode Penelitian (Methodology)}

\section{a. Metode dan Variabel Penelitian}

Metode penetian yang akan digunakan dalam penelitian ini adalah metode asosiatif dengan pendekatan kuantitatif. Metode asosiatif merupakan metode yang bertujuan untuk mengetahui pengaruh ataupun hubungan antara dua variabel atau lebih (Sugiyono, 2012:11).

Desain penelitian ini adalah terdiri dari 3 (tiga) variabel independen yaitu Motivasi kerja guru $\left(\mathrm{X}_{1}\right)$, Kompetensi guru $\left(\mathrm{X}_{2}\right)$ dan Kedisiplinan guru $\left(\mathrm{X}_{3}\right)$ terhadap variabel Dependen yaitu Kinerja guru $(\mathrm{Y})$. Adapun variabel, dimensi dan indikator pengukurnya di definisikan berikut ini.

Tabel 1. Operasional Variabel Penelitian

\begin{tabular}{|c|c|}
\hline Variabel & Dimensi \\
\hline $\begin{array}{l}\text { Motivasi guru } \\
\left(\mathrm{X}_{1}\right)\end{array}$ & $\begin{array}{l}\text { a. Motivasi internal } \\
\text { b. Motivasi eksternal } \\
\text { Sumber: Sritomo Wignjosoebroto (1999:42) }\end{array}$ \\
\hline $\begin{array}{l}\text { Kompetensi } \\
\left(\mathrm{X}_{2}\right)\end{array}$ & $\begin{array}{l}\text { a. Pedagogik } \\
\text { b. Kepribadian } \\
\text { c. Sosial } \\
\text { d. Profesional } \\
\text { (Sumber : Peraturan Pemerintah No.19 tahun 2005) }\end{array}$ \\
\hline $\begin{array}{l}\text { Disiplin } \\
\left(\mathrm{X}_{3}\right)\end{array}$ & $\begin{array}{l}\text { a. Kepatuhan terhadap peraturan-peraturan } \\
\text { b. Tanggung jawab } \\
\text { c. Kesadaran } \\
\text { (Sumber: Mangkunegara dan Octorent; 2015) }\end{array}$ \\
\hline $\begin{array}{l}\text { Kinerja Guru } \\
(\mathrm{Y})\end{array}$ & $\begin{array}{l}\text { Kemampuan kerja dan Hasil Kerja } \\
\text { (Sumber: Supardi, 2013:73) }\end{array}$ \\
\hline
\end{tabular}

\section{b. Populasi dan Sampel Penelitian}

Populasi dalam penelitian ini adalah seluruh guru pada SMA Negeri dalam Kecamatan Samalanga Kabupaten Bireuen berjumlah sebanyak 129 orang Guru, dan semua dijadikan objek penelitian (sampel jenuh).

\section{c. Alat Analisis}

Analisis jalur digunakan untuk mengetahui besarnya pengaruh suatu variabel terhadap variabel lainnya baik pengaruh langsung maupun tidak langsung (Nirwana, 2014:19-28; Robert D. Rutherford, dalam Marwan Hamid, dkk; 2019:10).

Untuk dapat menggunakan alat analisis ini, dipastikan data memiliki skala ukur minimal interval. Juga syarat statistik regresi dan analisis jalur, terpenuhinya semua asumsi klasik, yakni normalitas, heterosidasitas, multikolinieritas.

\section{Hasil dan Pembahasan (Results and Discussion)}

\section{a. Karakteristik Responden}

Responden dalam penelitian ini berjumlah 129 orang guru SMA di wilayah Kecamatan Samalanga Kabupaten Bireuen. Semua guru tersebut, PNS dan Non PNS di jadikan objek penelitian. Teknik pengumpulan data dengan menggunakan kuesioner yang disebar kepada seluruh guru, dengan jangka waktu yang telah tetapkan. Adapun karakteristik guru yang diteliti ini sebagaimana disajikan dalam tabel 2 berikut.

Tabel 2.

Karakteristik Data Guru Dan Karakteristiknya Kelamin

\begin{tabular}{|l|l|c|c|c|c|c|c|}
\hline \multirow{2}{*}{ No } & \multirow{2}{*}{ SMA } & \multicolumn{3}{|c|}{ Status Guru } & \multicolumn{3}{|c|}{ Masa Kerja Guru } \\
\cline { 3 - 8 } & & PNS & Kontrak/Honor & Guru Sertifikasi & $<10$ Thn & $10-15$ Thn & $>$. 15 Thn \\
\hline 1 & SMAN 1 & 25 & 39 & 15 & 39 & 5 & 20 \\
\hline 2 & SMAN 2 & 18 & 27 & 10 & 27 & 8 & 10 \\
\hline 3 & SMAN 3 & 7 & 13 & 5 & 13 & 3 & 4 \\
\hline \multicolumn{2}{r}{ Jumlah } & 50 & 79 & 30 & 79 & 16 & 34 \\
\hline
\end{tabular}

Sumber: Dinas Pendidikan Aceh, 2020 
Berdasarkan data tabel 2 diatas, maka terdapat 50 guru PNS dan 79 guru Non PNS, diantaranya terdapat 30 orang Guru sertifikasi, dengan mayoritas masa kerja kurang dari 10 Tahun.

\section{b. Hasil analisis Deskriptif}

Analisis deskriptif akan menunjukkan gambaran mengenai suatu data yang akan diteliti atau untuk menguraikan kecenderungan jawaban responden dari tiap-tiap variabel. Berdasarkan hasil kuesioner dari 129guru SMA Negeri di wilayah Samalanga Kabupaten Bireuen, diperoleh jawaban terhadap item pernyataan yang terkait dengan variabel Motivasi $\left(X_{1}\right)$, Kompetensi $\left(X_{2}\right)$, Disiplin kerja $\left(X_{3}\right)$, dan kinerja guru $(Y)$ sebagai berikut.

Tabel 3

Deskripsi Guru SMA Negeri di Samalanga Kabupaten Bireuen

\begin{tabular}{|c|c|c|c|c|c|c|}
\hline \multirow{2}{*}{ Variabel } & \multicolumn{5}{|c|}{ Persentase Jawaban } & \multirow{2}{*}{$\begin{array}{c}\text { Skor } \\
\text { Pencapaian }\end{array}$} \\
\hline & STS & TS & KS & $\mathbf{S}$ & SS & \\
\hline - $\quad$ Motivasi guru & 0.30 & 1.15 & 2.26 & 62.15 & 34.14 & 85.74 \\
\hline $\begin{array}{ll}- & \text { Kompetensi } \\
\end{array}$ & 0.27 & 1.31 & 3.37 & 36.46 & 58.59 & 90.36 \\
\hline - $\quad$ Disiplin kerja & 0.00 & 2.33 & 4.36 & 40.60 & 52.71 & 88.74 \\
\hline - $\quad$ Kinerja & 0.00 & 0.63 & 2.11 & 53.98 & 43.27 & 87.98 \\
\hline
\end{tabular}

Sumber: Penelitian Primer, 2021 (data diolah)

Catatan : $S S=$ Sangat setuju, $S=$ Setuju, KS=Kurang setuju, TS=Tidak setuju, STS=Sangat tdk setuju

Berdasarkan tabel di atas dapat dijelaskan bahwa :

1. Tingkat motivasi guru termasuk baik dalam mendukung kinerja. Skor penilaian motivasi guru mencapai $85,74 \%$

2. Kualitas Kompetensi guru, mendekati sempurna, menurut persepsi guru mencapai 90,36\%.

3. Faktor Disiplin guru sudah baik, mencapai $88,74 \%$ dari harapan,

4. Tingkat kinerja guru sudah mencapai kategori baik, yakni $87,98 \%$.

\section{c. Hasil Analisis Jalur}

Dengan pendekatan analisis jalur, yakni kombinasi regresi 2 variabel bebas terhadap variabel tak bebas (Kinerja guru) dan adanya hubungan kausalitas antar variabel bebas, dinyatakan dalam gambar 1.

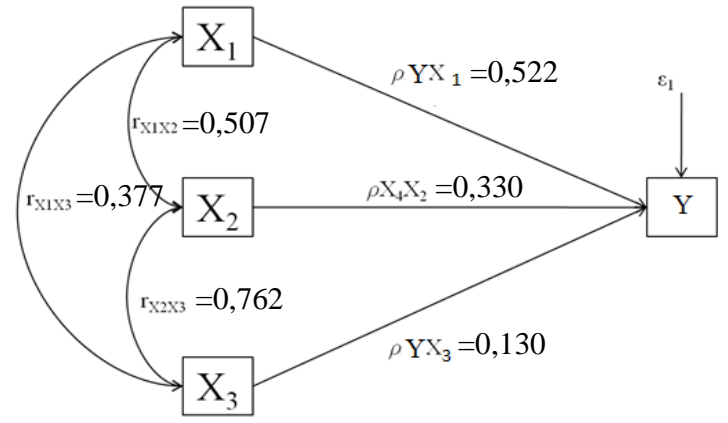

Gambar 1 Diagram Jalur Penelitian

\section{d. Uji Model}

Untuk dapat menyatakan bahwa hasil hitung koefisien korelasi $\left(\mathrm{r}_{\mathrm{xi}, \mathrm{x} j \mathrm{j}}\right)$ yang merupakan korelasi hubungan kausalitas antar variabel eksogen, dan signifikansi koefisien jalur yang merupakan koefisien pengaruh variabel eksogen terhadap endogen (Y), dilakukan pengujiannya.

Hipotesis 1: "Motivasi guru berpengaruh terhadap Kinerja guru".

Hipotesis ini menyatakan ada pengaruh motivasi guru terhadap kinerja guru SMA di wilayah Samalanga Kabupaten Bireuen. Hasil perhitungan uji individu menunjukkan harga $t_{\text {hitung }}$ sebesar 9,036. Dengan demikian $t_{\text {hitung }}>t_{\text {tabel }}(9,036>1,645)$. Sehingga Ho ditolak dan Haditerima artinya koefisien jalur variabel motivasi $\left(\mathrm{X}_{1}\right)$ terhadap kinerja guru $(\mathrm{Y})$. dapat dinyatakan signifikan pada taraf signifikan $\alpha=0,05$. Dengan demikian dapat dinyatakan bahwa terdapat pengaruh secara signifikan motivasi guru terhadap kinerja Guru yang diamati. 
Hipotesis 2: "Kompetensi berpengaruh terhadap Kinerja guru".

Hipotesis ini menyatakan ada pengaruh Kompetensi terhadap kinerja guru SMA yang diamati. Hasil perhitungan uji menunjukkan harga $t_{\text {hitung }}$ sebesar 3,990. Dengan demikiant $t_{\text {hitung }}>t_{\text {tabel }}(3,990>1,645)$. Sehingga Ho ditolak dan Ha diterima artinya koefisien jalur variabel kompetensi $\left(\mathrm{X}_{2}\right)$ terhadap kinerja guru (Y). dapat dinyatakan signifikan pada taraf signifikan $\alpha=0,05$. Dengan demikian dapat dinyatakan bahwa terdapat pengaruh secara signifikan kompetensi guru terhadap kinerja Guru SMA yang diteliti.

Hipotesis 3: "Disiplin kerja berpengaruh terhadap Kinerja guru".

Hipotesis ini menyatakan ada pengaruh disiplin kerja terhadap kinerja gur. Hasil uji individu menunjukkan harga $t_{\text {hitung }}$ sebesar 1,691. Dengan demikian $t_{\text {hitung }}>t_{\text {tabel }}(1,691>1,645)$. Sehingga Ho ditolak dan Ha diterima artinya koefisien jalur variabel disipln kerja $\left(\mathrm{X}_{1}\right)$ terhadap kinerja guru $(\mathrm{Y})$. dapat dinyatakan signifikan pada taraf signifikan $\alpha=0,05$. Dengan demikian dapat dinyatakan bahwa terdapat pengaruh secara signifikan disiplin kerja terhadap kinerja Guru SMA Negeri di wilayah Samalanga Kabupaten Bireuen.

\section{e. Pembahasan}

\section{1). Analisis Pengaruh Variabel Motivasi kerja terhadap Kinerja guru}

Sebagaimana dalam rancangan analisis, variabel independent dalam penelitian saling berhubungan atau kausalitas, sehingga variabel ini disebut eksogenus, dan penelitian ini merancang pada analisis jalur (Path Analysis). Maka akan terdapat pengaruh langsung dan pengaruh tidak langsung.

\section{Pengaruh langsung:}

Dari diagram 1, maka besarnya pengaruh langsung motivasi kerja terhadap kinerja guru, dihitung dari: $\left(\rho_{\mathrm{yx} 1}\right.$ )$^{2} 100 \%=(0,522)^{2} 100 \%$, sehingga besarnya pengaruh langsung ini adalah $27,25 \%$.

\section{Pengaruh Tidak langsung}

Besarnya pengaruh tak langsung motivasi kerja terhadap kinerja guru, yaitu:

- Pengaruh Motivasi melalui kompetensi terhadap Kinerja guru, sebesar 8,73\%

- Pengaruh Motivasi melalui disiplin kerja terhadap Kinerja guru, sebesar 2,56\%

\section{Pengaruh Total Motivasi kerja}

Berdasarkan pengaruh langsung dan tidak langsung, maka dapat dihitung besarnya pengaruh total motivasi kerja terhadap kinerja guru, yakni sebesar 38,54\%.

\section{2). Analisis Pengaruh Variabel Kompetensi terhadap Kinerja guru}

\section{Pengaruh langsung:}

Besarnya pengaruh langsung kompetensi terhadap kinerja guru, dengan perhitungan $\left(\rho_{\mathrm{yx} 2}\right)^{2} 100 \%=(0,330)^{2}$ $100 \%$, sehingga besarnya pengaruh langsung ini sebesar $10,89 \%$.

\section{Pengaruh Tidak langsung}

Besarnya pengaruh tak langsung kompetensi terhadap kinerja guru, yaitu:

- Pengaruh kompetensi melalui motivasi terhadap Kinerja guru, sebesar 8,73\%

- Pengaruh kompetensi melalui disiplin kerja terhadap Kinerja guru, sebesar 3,27\%

\section{Pengaruh Total Kompetensi guru}

Berdasarkan pengaruh langsung dan tidak langsung, maka dapat dihitung besarnya pengaruh total kompetensi guru terhadap kinerja guru sebesar $22,89 \%$.

\section{3). Analisis Pengaruh Variabel Disiplim kerja terhadap Kinerja guru}

\section{Pengaruh langsung:}

Besarnya pengaruh langsung disiplin kerja terhadap kinerja guru, dinyatakan dengan perhitungan $\left(\rho_{\mathrm{yx} 3}\right)^{2} 100 \%=(0,130)^{2} 100 \%$, sehingga besarnya pengaruh langsung ini sebesar $1,69 \%$.

\section{Pengaruh Tidak langsung}

Besarnya pengaruh tak langsung disiplin kerja terhadap kinerja guru, yaitu:

- Pengaruh disiplin kerja melalui Motivasi guru terhadap kinerja guru, sebesar 2,56\%

- Pengaruh disiplin kerja melalui kompetensi terhadap kinerja guru, sebesar 3,27\% 


\section{Pengaruh Total Disiplin kerja}

Berdasarkan pengaruh langsung dan tidak langsung, maka dapat dihitung besarnya pengaruh total disiplin kerja terhadap kinerja guru, yakni sebesar 7,52\%.

\section{4). Analisis Pengaruh Variabel Motivasi kerja, Kompetensi, dan Disiplin terhadap Kinerja guru} SMA Negeri di Samalanga Kabupaten Bireuen

Hasil persamaan jalur dinyatakan sebagai berikut:

$$
\begin{gathered}
\mathrm{Y}=\rho_{\mathrm{Yx} 1}+\rho_{\mathrm{Yx} 2}+\rho_{\mathrm{Yx} 3}+\rho_{\mathrm{Yx} 4}+\varepsilon=\mathbf{0 , 5 2 2} \mathrm{X}_{1}+\mathbf{0 , 3 3 0} \mathrm{X}_{2}+\mathbf{0 , 1 3 0} \mathrm{X}_{3} \\
\left(\mathrm{Y}=\text { Kinerja guru, } \mathrm{X}_{1}=\text { Motivasi guru, } \mathrm{X}_{2}=\text { Kompetensi, } \mathrm{X}_{3}=\text { Disiplin kerja }\right)
\end{gathered}
$$

Nilai koefisien jalur Motivasi guru bernilai positif $(0,522)$ artinya semakin baik motivasi yang dimiliki seorang guru dalam bekerja, maka akan semakin meningkat Kinerja guru SMA Negeri di wilayah Samalanga Kabupaten Bireuen, dengan rata-rata kenaikan 0,522.

Koefisien jalur kompetsnsi bernilai positif $(0,330)$ artinya apabila kompetensi guru diupayakan baik dalam mendukung pekerjaan guru, maka akan meningkat kinerja guru, dengan rata-rata 0,330.

Koefisien jalur Disiplin kerja bernilai positif $(0,130)$ artinya apabila disipln guru di sekolah teratur dan dijalankan sesuai aturan, akan berdampak positif terhadap Kinerja kerja guru, dengan rata-rata kenaikannya 0,130 .

Kemudian nilai statistik R-square yakni determinasi variabel eksogen terhadap endogen sebagaimana dinyatkan (Ghozali, 2012) mengukur kontribusi variabel bebas (X) dengan variabel terikat (Y) yang dapat dilihat dari tabel berikut:

Tabel 4. Koefisien Korelasi Simultan

\begin{tabular}{|c|c|c|c|}
\hline $\mathrm{R}$ & R Square & Adjusted R Square & Std. Error of Estimate \\
\hline $.830^{\mathrm{a}}$ & .690 & .682 & 2.83142 \\
\hline
\end{tabular}

Nilai koefisien determinasi sebesar 0,690 menjelaskan bahwa kontribusi faktor motivasi guru, kompetensi guru dan disiplin kerja terhadap kinerja guru SMA Negeri di wilayah Samalanga Kabupaten Bireuen, sebesar $69 \%$. Sementara sisanya dari peran variabel yang tidak diteliti yakni sebesar $31 \%$.

\section{Simpulan (Conclusion)}

Hasil analisis deskriptif menunjukkan bahwa tingkat motivasi guru mencapai 85,74\%, tingkat Kompetensi guru, mencapai 90,36\%, dan disiplin kerja sudah menunjukkan hal yang baik, mencapai 88,74\% dari yang diharapkan untuk meningkatkan kinerja guru.

Demikian juga dari hasil analisis jalur, membuktikan secara statistik bahwa factor yang diduga pengaruhnya pada kinerja guru ini, diperoleh bahwa; 1) pengaruh Motivasi guru sebesar 38,54 \%. 2) pengaruh faktor Kompetensi guru sebesar 22,89\%. 3). Sedangkan faktor Disiplin kerja menunjukkan adanya pengaruhnya terhadap kinerja guru, yakni sebesar 7,52\%.

Hasil analisis dari nilai koefisien determinasi menjelaskan bahwa kontribusi faktor Motivasi guru, Kompetensi guru dan Disiplin kerja terhadap Kinerja guru SMA Negeri di wilayah Samalanga Kabupaten Bireuen, sebesar $69 \%$. Sementara sisanya dari peran variabel yang tidak diteliti yakni sebesar $31 \%$. Hal ini menujukkan bahwa terdapat faktor-faktor lain yang dapat mempengaruhi variabel kinerja guru, seperti iklim organisasi, fasilitas kerja, Pendidikan dan Pelatihan.

\section{DAFTAR PUSTAKA (References)}

1) A. A Anwar Prabu Mangkunegara, 2015. Manajemen Sumber Manusia Perusahaan. Bandung. Bandung : PT Remaja Rosdakarya

2) B. Uno, Hamzah. 2013. Teori Motivasi dan Pengukurannya. Jakarta: Bumi Aksara

3) Hasibuan, Malayu, 2007. Organisasi dan Motivasi. PT. Bumi Aksara, Jakarta

4) Imam Wahyudi. 2012. Mengejar Profesionalisme Guru. Jakarta: Prestasi Pustaka.

5) Marwan Hamid, Ibrahim Sufi, Win Konadi, dan Yusrizal Akmal, 2019. Analisis Jalur Dan Aplikasi Spss Versi 25, Edisi Pertama Sefa Bumi Persada, Medan.

6) Mulyasa. 2005. Menjadi Kepala Sekolah Profesional. Bandung: PT Remaja Rosdakarya.

7) Mulyasa, 2007. Menjadi Guru Profesional Menciptakan Pembelajaran yang Kreatif dan Menyenangkan. PT Remaja Rosda karya, Bandung 
8) Nana Syaodih Sukmadinata. 2009. Landasan Psikologi Proses Pendidikan. Bandung: PT Remaja Rosdakarya.

9) Notoatmodjo, Soekidjo, 2009. Pengembangan Sumber Daya Manusia. PT Rineka Cipta, Jakarta

10) Oemar Hamalik. 2004. Proses Belajar Mengajar. Jakarta: PT Bumi Aksara.

11) Peraturan Menteri Pendidikan Nasional Republik Indonesia Nomor 16 Tahun 2007 Tentang Standar Kualifikasi Akademik Dan Kompetensi Guru,

12) Peraturan pemerintah no. 19 tahun 2005 tentang standar pendidikan nasional

13) Robbins, S. P., dan Judge, Timothy A., 2008. Perilaku Organisasi Edisi keduabelas Salemba Empat, Jakarta.

14) Ruky, Achmad, 2006. Sumber Daya Manusia Berkualitas mengubah Visi menjadi Realitas. PT. Gramedia Pustaka Utama, Jakarta.

15) Siagian, S. P., 2004. Manajemen Internasional. PT Bumi Aksara, Jakarta.

16) Sugiyono. 2010. Statistika untuk Penelitian. Bandung: CV Alfabeta.

17) Suyuti, Achmad. 2001. Pelatihan Dasar Kepemimpinan (Leadership) dari Aspek Etik dan Moral. Pekalongan: Cinta Ilmu.

18) Supardi. 2013. Kinerja Guru. Jakarta: PT Rajagrafindo Persada.

19) Sritomo Wignjosoebroto. 1999. Perspektif Pembangunan Daya Saing Global. Tenaga Kerja Profesional Simposium (Desember), Jakarta

20) Undang-undang Republik Indonesia Nomor 14 Tahun 2005 tentang Guru dan Dosen.

21) Veithzal, Rivai, 2008. Performance Appraisal: Sistem Yang Tepat Untuk Menilai Kinerja Karyawan Dan Menigkatkan Daya Saing Perusahaan. PT Rajagrafindo Persada, Jakarta.

22) Veithzal, Rivai, dan Ella, Jauvani, 2009. Manajemen Sumber Daya manusia untuk Perusahaan. PT Rajagrafindo Persada, Jakarta.

23) Wibowo, 2008. Manajemen Kinerja. PT grafindo Persada. Jakarta.

24) Wukir, 2013, Manajemen Sumber Daya Manusia Dalam Organisasi Sekolah,. Cetakan I, Multi Presindo, Yogyakarta 